\title{
Short Communication: \\ Carbon sequestration by young Rhizophora apiculata plants in Kubu Raya District, West Kalimantan, Indonesia
}

\author{
RINTO WIARTA ${ }^{1}$, YULIATI INDRAYANI ${ }^{2}$, FAIRUZ MULIA ${ }^{3}$, DWI ASTIANI ${ }^{2, v}$ \\ ${ }^{1}$ Faculty of Enginering, Universitas Nahdatul Ulama Kalimantan Barat. Jl. KH Ahmad Dahlan no.72, Pontianak 78116, West Kalimantan, Indonesia \\ ${ }^{2}$ Faculty of Forestry, Universitas Tanjungpura. Jl. Prof. Hadari Nawawi, Pontianak 78124, West Kalimantan, Indonesia. Tel.: +62-561-765342, \\ "email: astiani.dwi@gmail.com \\ ${ }^{3}$ PT. Kandelia Alam, Kubu Raya District, West Kalimantan, Indonesia
}

Manuscript received: 12 October 2018. Revision accepted: 7 January 2019.

\begin{abstract}
Wiarta R, Indrayani Y, Mulia F, Astiani D. 2019. Short Communication: Carbon sequestration by young Rhizophora apiculata plants in Kubu Raya District, West Kalimantan, Indonesia. Biodiversitas 20: 311-315. Mangrove forest ecosystem has been known for its roles in buffering coastal abrasions and being a reservoir for seafood production. However, very little information is available on its role in sequestering carbon and how its annual growth ability can benefit climate change mitigation. This study aims to determine carbon storage and sequestration by one, three and five-year-old Rhizophora apiculata Blume planted in PT. Ovivipari Bina Semesta (PT. BIOS). This study was conducted for over five months during 2015-2016, in purposively selected mangrove rehabilitation area. It used both harvestings as well as non-harvesting methods for estimation of carbon stock and carbon sequestration. The results show that the mangrove species has a very high ability to sequester carbon per unit area. The amount of carbon stored in plants aged 1 year, 3 years and 5 years were 0.363 tonnes $\mathrm{ha}^{-1}, 5,591$ tonnes $\mathrm{ha}^{-1}$ and 7,240 tons ha $\mathrm{s}^{-1}$, respectively. The study also indicated that the carbon stock values obtained by non-harvesting method using allometric equation were higher than the values obtained by harvesting method.
\end{abstract}

Keywords: Annual growth, carbon sequestration, mangrove ecosystem, PT. BIOS

\section{INTRODUCTION}

Mangroves are one of the wetland forest types in Indonesia, which creates its own and unique ecosystems. Unlike other types of forests, unique characteristics of mangroves are due to the influence of tide, the muddy ground habitat, and saline water ecosystem(Komiyama et al. 2005). This ecosystem cannot be found on large wavy coastal area. Mangrove vegetation generally grows to form zoning starting from the beach to a few meters inland (Poedjirahajoe 2007). Bismark et al. (2008) mentioned that mangrove forests, in addition to functioning as a physical buffer against coastal erosion, also provide food for human life, especially fish, shrimp, scallops and crab; as well as energy for life on the beach such as plankton, nekton and algae. The extent of mangroves in Indonesia is around 4.5 million hectares which is almost $25 \%$ of the total mangrove forest in the world (18 million hectares) and it also forms $3.8 \%$ of the total forest area in Indonesia as a whole (Cheong et al., 1990). Indonesian mangrove forests existing at present is actually only $65 \%$ of the original mangrove area that existed in the past.

Mangrove forests also inhabit the coastal area of West Kalimantan. The extent was about 565 thousand hectares in 1995 which declined to $\sim 351 \times 103$ ha by 2011 , and the present extent is $1,13,857.1$ hectares (Hardiansyah et al. 2014). This is because, all over the globe including Indonesia, destruction of mangrove ecosystems is taking place in a large scale due to various reasons such as developing of shrimp ponds, felling of mangrove forests, environmental pollution, reclamation and sedimentation, mining, natural causes such as hurricanes/tsunami and others. Forest degradation or destruction has significant impact on in situ forest dynamics, such as trees growth and mortality (Astiani 2016), which also affects its potential on carbon storage and sequestration (Astiani et al. 2017).

Mangrove trees and plants demonstrate a high rate of growth, which is coupled with water-logging and anaerobic condition, resulting in significantly large and long-term carbon storage potential (Murdiyarso et al. 2015). Mangrove forest ecosystems have a significant role as absorber of carbon dioxide $\left(\mathrm{CO}_{2}\right)$ from global atmosphere, therefore they are relevant to global issue of climate change mitigation. The mangrove forests act as carbon sinks, through the process of photosynthesis they transform inorganic carbon $\left(\mathrm{CO}_{2}\right)$ into organic carbon which is stored in the form of standing biomass. Along with carbon sequestration through the photosynthetic process, only part of its fallen litter is decomposed to release carbon back into the atmosphere in the form of $\mathrm{CO}_{2}$, while a larger part of the debris is brought to the sea where it is maintained in the form of blue carbon. However, mangrove forests contain a large amount of organic material that does not decompose quickly. Therefore, mangrove forests could serve both faster carbon sequestration and long-term storage. On the contrary, the current large-scale ongoing mangrove deforestation would lead to carbon emission and in many ways, accelerate the release of carbon into the atmosphere 
(Hamilton \& Fries 2018) and contribute to global warming.

One of the mangrove species, i.e., Rhizophora apiculata Blume has a high potential to absorb carbon than other species of plants. Its wood mass per unit area is large because the average bulk density is relatively high compared to other species, which range 0.81-0.94 $\mathrm{g} / \mathrm{cm}^{3}$ (Pambudi 2011). Planting area PT Bina Ovivipari Semesta is an ex-felling area of $R$. apiculata species, which has become a forest that serves as a recovery of the logged and wood collection area. This area is not only able to create new ecological systems and micro-climates but with the new plants that grow in the area, is also functioning as a carbon sink. There is no data and information on the carbon sequestration potential of the ex-logged areas. Considering the importance of the development and management of these areas, it is necessary to study the carbon sequestration capability of the associated species, which may be used as baseline data for the management and development of the PT Bina Ovivipari Semesta. The knowledge can also be utilized as an incentive to maintain it continuously as a carbon sink area. In this study, an effort has been made to determine the carbon sequestration potential of Rhizophora apiculata plants of different ages, both by non-destructive and destructive methods.

\section{MATERIALS AND METHODS}

\section{Study site}

This research was conducted in the area of rehabilitation of ex-felling IUPHHKHA PT. Bina Ovivipari Semesta, Subdistrict of Batu Ampar, District of Kubu Raya, West Kalimantan, Indonesia. Bina Ovivipari Semesta Company obtained a Business License to use Natural Forest Wood Forest Products (IUPHHK-HA) through Decree No. 68 / MENHUT-II / 2006 on March 27, 2006 , from an area of $\pm 10,100$ ha in Kubu Raya District, West Kalimantan. Out of this forest concession area of $10,100 \mathrm{ha}$, the effective area for production is 5,642 ha $(57 \%)$, while the remaining area of 4,458 ha $(43 \%)$ is designated as protected areas, non-production areas and non-forest areas (PT BIOS Data 2009). The mangrove area of this region could be classified as a coastal mangrove, where the stand of $R$. apiculata species is found along the perimeter of the mangrove island. The current study was conducted for about five months period during the year 2015-2016. The study was conducted particularly in the areas where tree cutting was done during the years 2010, 2012, and 2014.
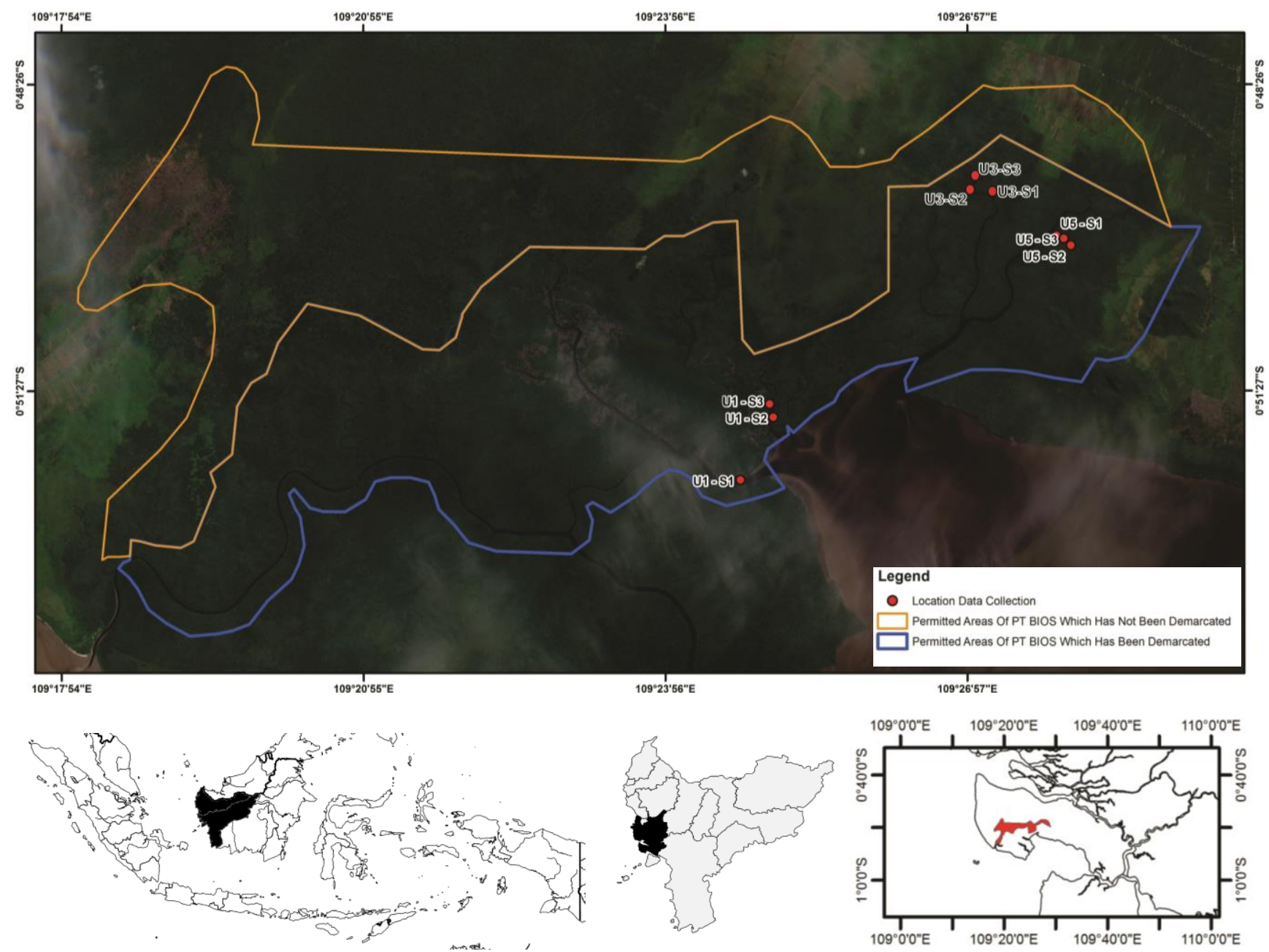

Figure 1. Map of the study area showing the research sites in IUPHHKHA PT. Bina Ovivipari Semesta, Subdistrict of Batu Ampar, District of Kubu Raya, West Kalimantan, Indonesia 

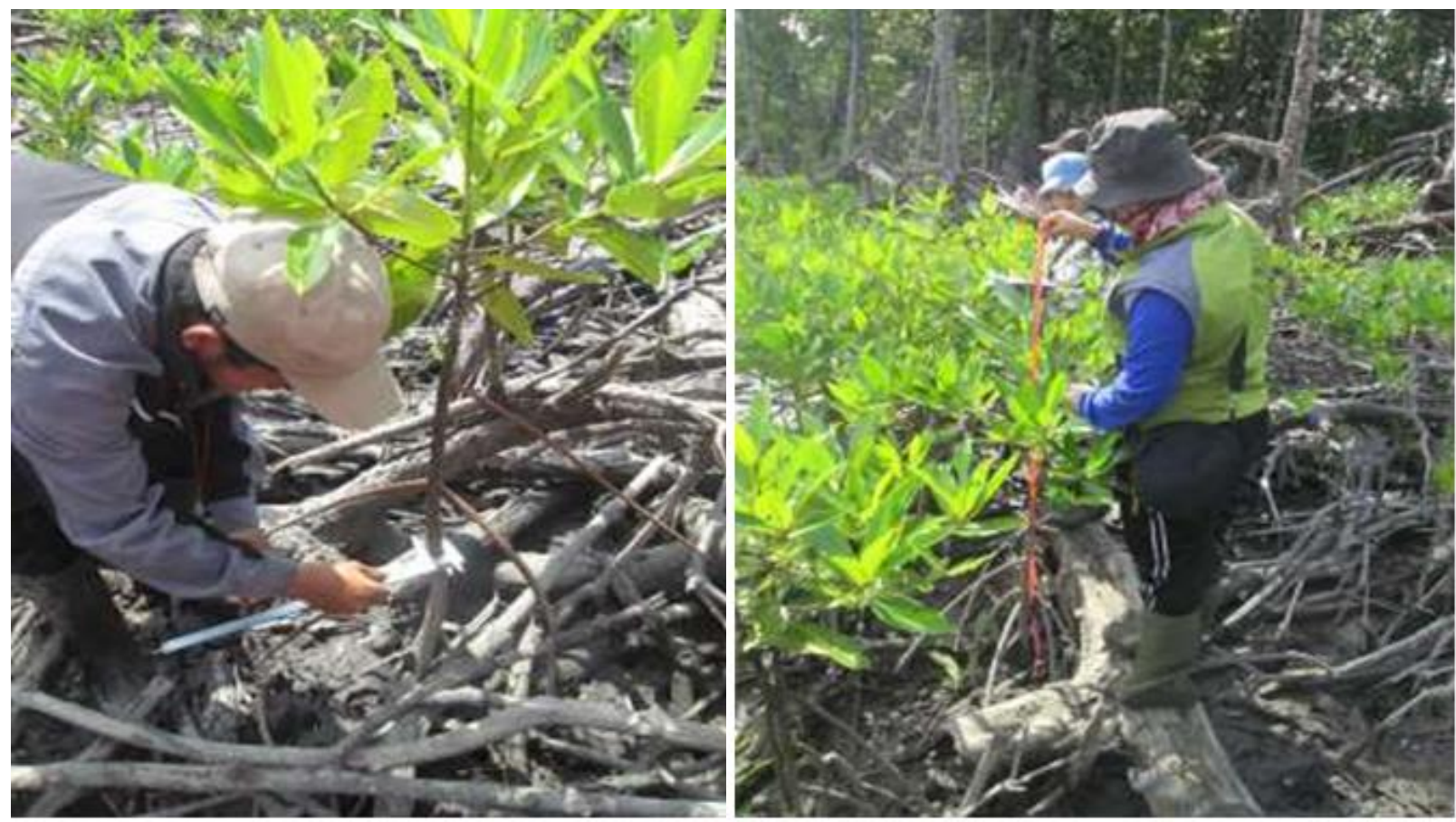

Figure 2. Measurement one-year-old Rhizophora apiculata plants

\section{Field data collection}

Mangrove plantations consisting of one, three and fiveyear-old Rhizophora apiculata plants were used for this study. For the biomass estimation, some tools such as GPS, compass, clinometer, camera, ropes, saws, hoes, baskets, buckets, machetes, scales, plastic, tape measure, phi band, plastic labels, sacks, water pump, water hoses and stationery were used.

Wood biomass was calculated by both destructive or harvesting and non-destructive or without harvesting methods. $20 \mathrm{~m} \mathrm{X} 20 \mathrm{~m}$ plots were used for data collection. For each plant age group, data was collected from 15 plots, and in total, data was collected from 45 research plots. Diameter of stilt root height was measured for all plants in the plots. For 1, 3 and 5-year-old plants, non-destructive method was used by applying the already available allometric equation. Harvesting method was also applied for calculating actual biomass of 1 and 3-year-old plants, which involved harvesting all the above-ground and belowground parts, including roots, trunk, branches, twigs, and leaves. Tree biomass assessment activities are shown in Figure 2.

\section{Data analysis}

Biomass by indirect or non-harvesting method was calculated using the allometric equation $\mathrm{B}=0.043 \mathrm{D}^{2.63}$ (Amira 2008), where $\mathrm{B}$ is the biomass and $\mathrm{D}$ represents diameter (dbh). In the harvesting method, biomass (dry weight) was calculated using the equation of Haygreen and Bowyer (1982) as explained by Amira (2008) which is shown below:

$$
\begin{aligned}
& B K=\frac{B B}{1+\left(\frac{\% K A}{100}\right)} \\
& \% K A=\frac{B B c-B K c}{B K c} \times 100 \%
\end{aligned}
$$

Where: $\mathrm{BK}=$ Dry weight $(\mathrm{g}), \quad \mathrm{BKC}=\mathrm{dry} \quad$ weight $\quad$ of sample $(\mathrm{g}), \mathrm{B}=$ wet weight $(\mathrm{g}), \mathrm{BBC}=$ weight of the wet sample $(\mathrm{g})$, and $\% \mathrm{KA}=$ the water content. Further, amount of carbon stock in biomass was estimated by determining the total biomass, as follows:

Total Biomass (Dry weight in tones $)=\mathrm{BK}_{1}+\mathrm{BK}_{2}+\mathrm{BK}_{3}+\ldots . \mathrm{BK}_{\mathrm{n}}$, $\mathrm{BK}_{\mathrm{i}}$

To calculate the amount of carbon stored in an area of plantation sample, the following equation was used:

Total Carbon stored (Ton ha-1) $=\Sigma$ tree dry weight of plant biomass) $\mathrm{x}$ carbon content) $\mathrm{x}$ (ha-1x measurement area-1)

\section{RESULTS AND DISCUSSION}

Carbon stock is basically the total amount of carbon stored in vegetation, other biomass and in soil, while carbon sequestration is the amount of carbon absorbed per unit area and time which represents the process of carbon storage in growing plants (Ariani et al. 2014). This study determines the carbon storage and carbon sequestration by different age classes of Rhizophora apiculata plants, which is shown in Table 1. 
Table 1. Total carbon stocks and sequestration by different age classes of Rhizophora apiculata plants, calculated based on allometric equation

\begin{tabular}{ccc}
\hline $\begin{array}{c}\text { Age of plants } \\
\text { (in years) }\end{array}$ & $\begin{array}{c}\text { Total carbon content } \\
\text { (tonnes/ha) }\end{array}$ & $\begin{array}{c}\text { C sequestration (tones } \\
\text { ha-1 }^{-1} \text { year }^{-1} \text { ) }\end{array}$ \\
\hline 1 & 0.363 & 0.36 \\
3 & 5.591 & 1.85 \\
5 & 7.240 & 1.46 \\
\hline
\end{tabular}

Table 2. Total carbon stocks and sequestration by different age classes of $R$. apiculata plants, calculated based on direct estimation of biomass

\begin{tabular}{ccc}
\hline Age (years) & $\begin{array}{c}\text { Carbon stocks } \\
\text { (tones/ha) }\end{array}$ & $\begin{array}{c}\text { C sequestration (tones ha- } \\
\text { 1 }^{-1} \text { year }^{-1}\end{array}$ \\
\hline 1 & 0.481 & 0.48 \\
3 & 0.746 & 0.26 \\
5 & 1.19 & 0.23 \\
\hline
\end{tabular}

Plant growth and age affects the amount of carbon deposited in each ecosystem. This study has shown that 5year-old plants of $R$. apiculata can have a carbon stocking of 7.2 tones ha-1 (Table 1) and carbon sequestration of 1.46 tones $\mathrm{ha}^{-1}$ year ${ }^{-1}$. This is surely much less when compared to that estimated for 20-year-old mangrove trees with the carbon storage of 114 ton ha $^{-1}$ (Jin-Eong et al., 1995). As the plants mature, the carbon stored in them also increases. The young trees of $<5$ year age contribute only about $6.4 \%$ of the carbon stock. However, since the mangroves grow relatively fast during the later stages of growth, based on values of mean carbon stocks of different age classes, this ecosystem may sequester, on an average, 7.12 tonnes of carbon $\mathrm{ha}^{-1}$ year ${ }^{-1}$. Therefore, it is important to take care of and enrich young stands of mangroves to be a potential stock of carbon, in the future.

For the sake of comparison with carbon stock and sequestration values obtained by allometric equation given by Amira (2008), carbon stock and sequestration were also determined by harvesting and measuring the actual biomass of 1 year and 3-year-old trees. For 5-year-old plants, such a value was obtained from available literature (Darussalam 2011). The result of such actual biomass measurement is shown in Table 2.

When compared table 1 and 2, the values obtained from equation by Amira (2008) is apparently over estimates the carbon, when compared to the actual biomass measurement, which has indicated a much lower carbon stock per hectare except for one-year-old trees. Within each mangrove landscape or ecosystem, the amount of carbon stock or sequestered is relatively different. The fluctuation is influenced by diversity and the complexity of the components that make up the ecosystem. Larger diameter trees sequestered more carbon compared to smaller one or annual plants. Therefore, natural forests with high diversity of tree species that grow older or longer period of time, they may store much more carbon in their biomass (Dharmawan and Samsoedin 2012; Panggabean et al. 2012). Panggabean et al. (2012) reported that large- diameter trees growing for many years in the forest stocked much greater biomass. Different results may also due to many site factors which influence the growth of young stands of mangrove forests. For example, one major factor that results in high uptake and carbon storage in plants is soil fertility. Rusdiana (2012) showed that higher the fertility of the soil, greater is the expected plant growth, so that the greater amount of carbon will be stored in the stand, litter, and soil. Therefore, in the long term, it is important to maintain suitable site conditions that enhance the growth of young mangrove plants, so that these plants can sequester higher amount of carbon in their biomass mitigate GHG emission by reducing $\mathrm{CO}_{2}$ concentration in the atmosphere.

\section{REFERENCES}

Amira, S. 2008. An estimation of Rhizophora apiculata B1. biomass in mangrove forest in Batu Ampar Kubu Raya Regency, West Kalimantan.

[Hon. Thesis]. Bogor Agricultural University, Bogor. [Indonesian]

Ariani, Sudhartono A, Wahid A. 2014. Biomass and carbon plant down around Lake Tambing In Lore Lindu National Park area. News Jungle 2 (1): $164-170$.

Astiani D. 2016. Tropical peatland tree species diversity altered by forest degradation. Biodiversitas 17 (1): 102-109.

Astiani D, Mujiman, Rafiastanto A. 2017. Forest type diversity on carbon stocks: Cases of recent land cover conditions of tropical lowland, swamp, and peatland forests in West Kalimantan, Indonesia. Biodiversitas 18 (1): 137-144.

Cheong ET, Suminar S, Achmadi. 1990. Mangrove forest in Indonesia. For Ecol Manag 33-34: 45-57.

Dharmawan IWS, Samsoedin I. (2012). The dynamics of the potential of carbon biomass at logged forest landscape in the forest Malinau's research. J Soc Res For Econ 9 (1): 12-20.

Bismark M, Subiandono E, Heriyanto NM. 2008. Diversity and Potential of Carbon Content Type And Mangrove Forests Subelen In Sungai Siberut, West Sumatra. J For Res Nat Conserv 5 (3): 297-306.

Darussalam D. 2011. Prediction of Potential carbon uptake in stands of pine in Cianjur KPH Perhutani Unit III West Java and Banten. Essay. Department of Forest Management, Faculty of Forestry, Bogor Agricultural Institute, Bogor

Hamilton SE, Fries DA. 2018. Global carbon stocks and potential emissions due to mangrove deforestation from 2000 to 2012. Nature Clim Ch 8: 240-244.

Hardiansyah G, Yani A, Jamani R, Fahrizal, Erianto, Yuslinda, Jeno M, Ngo LY, Manuputty BDR, Darmawel, Yenny, Sari SE, Rosadi, Haryono Z, Iskandar, Idham M, Ilyas, Zailani, Sholatiana, Irvanto FA. 2014. Strategy and Action Plan REDD + KALBAR Province. Tanjungpura University Press, Pontianak.

Komiyama A, Poungpam S, Kato S. 2005. Common allometric equation for estimating the tree weight of mangroves. J Trop Ecol 21: 471-477.

Murdiyarso D, Purbopuspito J, Kauffman JB, Warren MW, Sasmito SD, Donato DC, Manuri S, Krisnawati H, Taberima S, Kurnianto S. 2015. The potential of Indonesian mangrove forest for global climate change mitigation. Nature Clim Ch 5: 1089-1092.

Pambudi GP. 2011. Several biomass administration of age types of plants Rhizophora apiculata Bl. in the area of PT. Bina Ovivipari Semesta Kubu Raya District, West Kalimantan. Department of Forestry and Ecotourism Conservation, Faculty of Forestry. Bogor Agricultural University, Bogor.

Panggabean MLS, Rahmawati, Riswan. 2012. Estimation of Above Ground Biomass Carbon Stock (AGB) On Natural Forest Standing in Langkat. [Thesis]. Faculty of Agriculture, University of North Sumatra, Medan. [Indonesian]

Poedjirahajoe E. 2007. Growth zoning dendrogram based mangrove rehabilitation region habitat in Central Java North Coast Section West. J For Sci 1 (2): 10-21.

PT. BIOS. 2010. Companies Bina Ovivipari Universe. Books Work Plan 2010. Utilization of wood-based forest inventory comprehensive 
periodic (IHMB) PT. Bina Ovivipari Universe period of $2012 \mathrm{~s} / \mathrm{d}$ 2021 Kubu Raya regency in West Kalimantan. PT. BIOS, Kubu Raya. [Indonesian]
Rusdiana O, Lubis RS. 2012. Estimation of correlation between soil characteristics reserves against carbon (carbon stock) In the secondary forest. J Trop Silvicult 3 (3): 14-21. 